\title{
PLANTS
}

\section{ORCHIDS OF THE PRAIRIE PROVINCES}

\section{GARTH NELSON, 529 Dalhousie Crescent, Saskatoon, SK. S7H 3 S5}

"Orchid." The word has an exotic ring to it. There is a mystique about these strange and beautiful flowers that conjures images of steamy jungles, tropical islands and other faraway places. We see them mostly in conservatories, on corsages, or potted and decorating someone's solarium. In conversations I have had with people, it comes as a surprise that there are orchids growing wild across the prairie provinces. Yet Budd's Flora' lists 34 species of orchids, and 21 orchid species are mentioned - most of them with pictures - in Wildflowers Across the Prairies, $^{2}$
It is exciting to think of so many kinds of orchids growing in our own region; even more exciting to realize that they are part of such a huge, diverse and fascinating family.

Orchids are found in almost every area, latitude, and elevation of the earth. The range of some is as broad as an entire continent, while that of others is limited to a single valley or mountain. The blossoms of some species are so small that one of them would fit into the zero at the bottom of our ten cent piece. Other orchid plants are huge. There are species that grow in Southeast Asia and Polynesia whose stems are

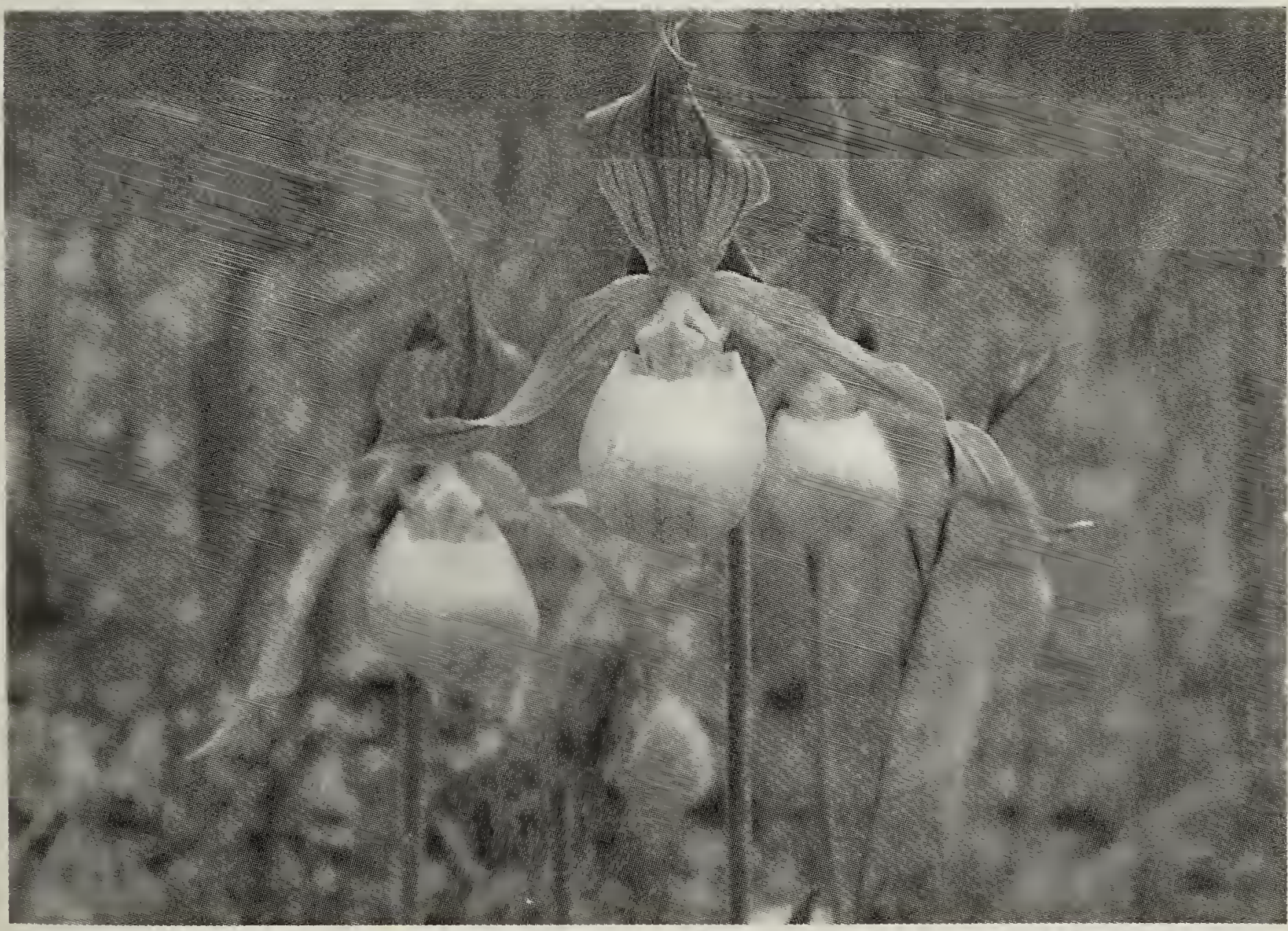




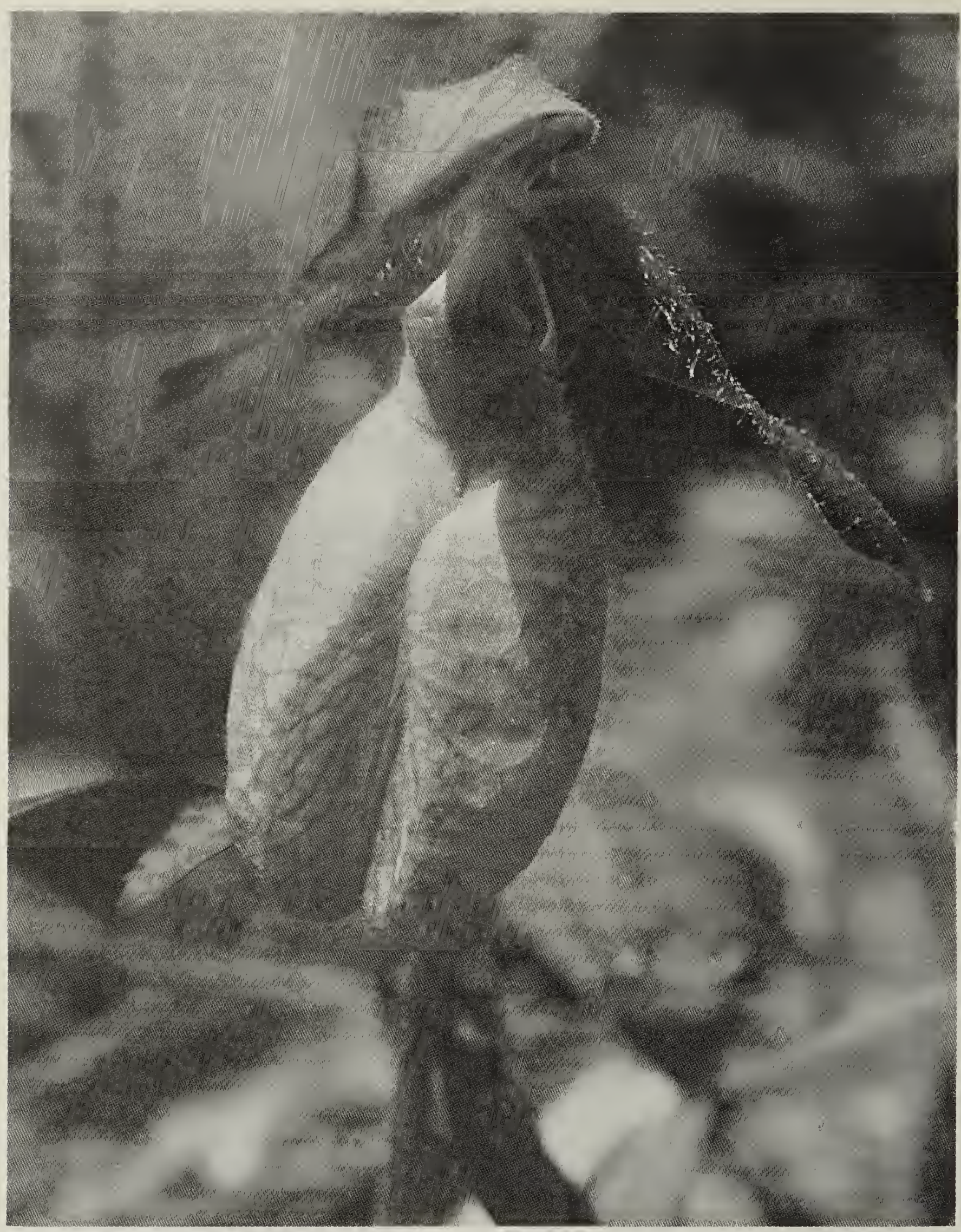

several meters high and whose entire weight is in the neighbourhood of a ton. The epiphytic orchids grow on tree trunks and branches, getting their nourishment from the air and from rain water and using the tree as an anchoring support. Many are terrestrial, growing from the ground as do most flowers with which we are familiar. Still others are aquatic and have their feet in water. There are some members of this family of plants that even grow underground. Two Australian species spend their lives almost completely below the surface of the soil, their flowers appearing above ground only enough to allow pollination by small flies, termites or beetles.

Orchids have intriguing ways of attracting insects and of getting them to work for them. 


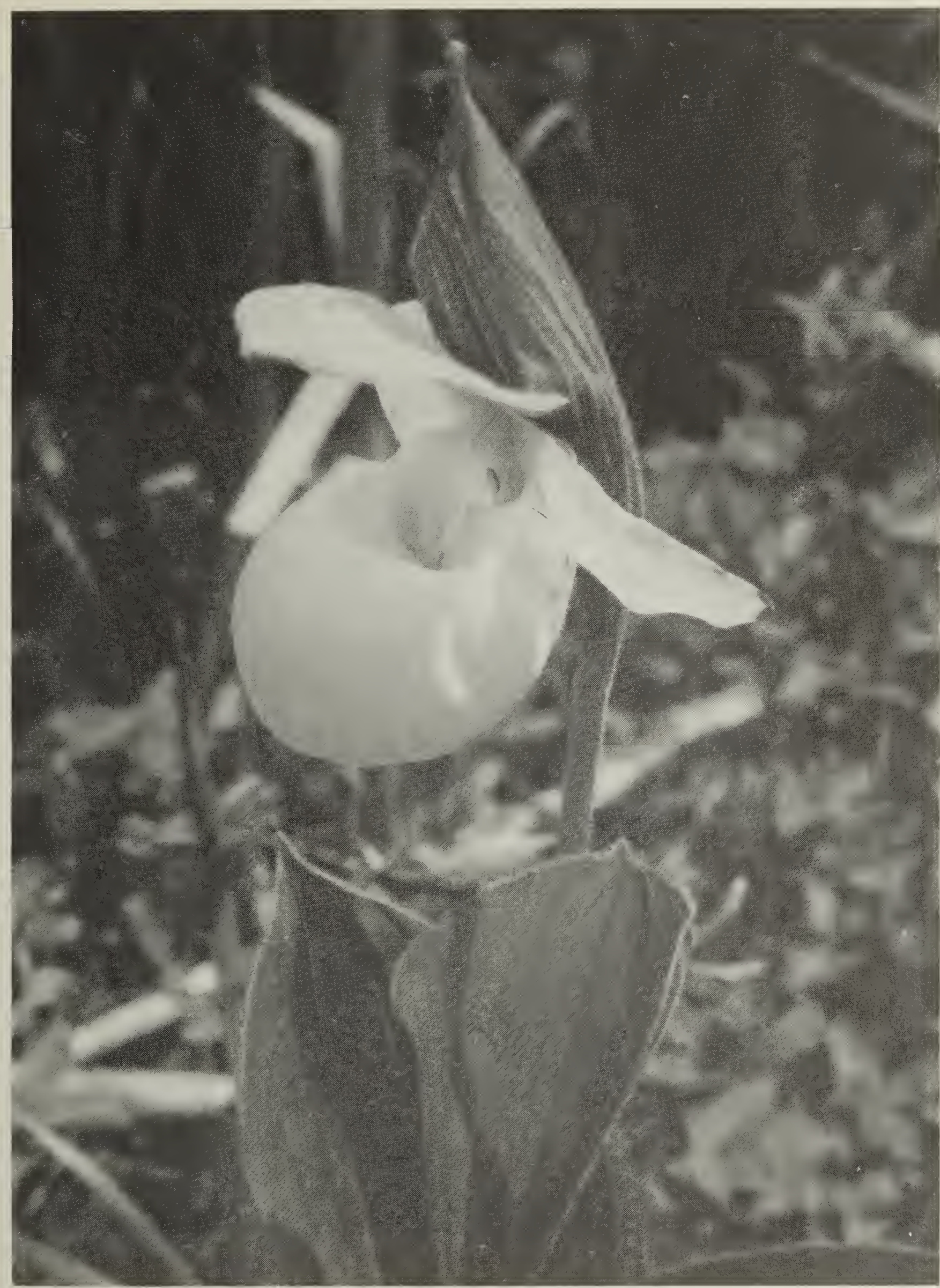

Some of the most beautiful flowers in the world are orchids. But there are also members of this family that are ugly - even grotesque. Many have alluring fragrance to order to attract pollinators, while others smell like rotting carrion for the same purpose. Many of them have symbiotic relationships with fungi.
The diversity and fascinating character of orchid flora is evident amongst the species that call our prairie provinces home. Perhaps the most familiar of orchids is the Yellow Lady's-slipper (Cypripedium calceolus) which is found across Canada and as far north as the Yukon Territory. I remember it, with warm 


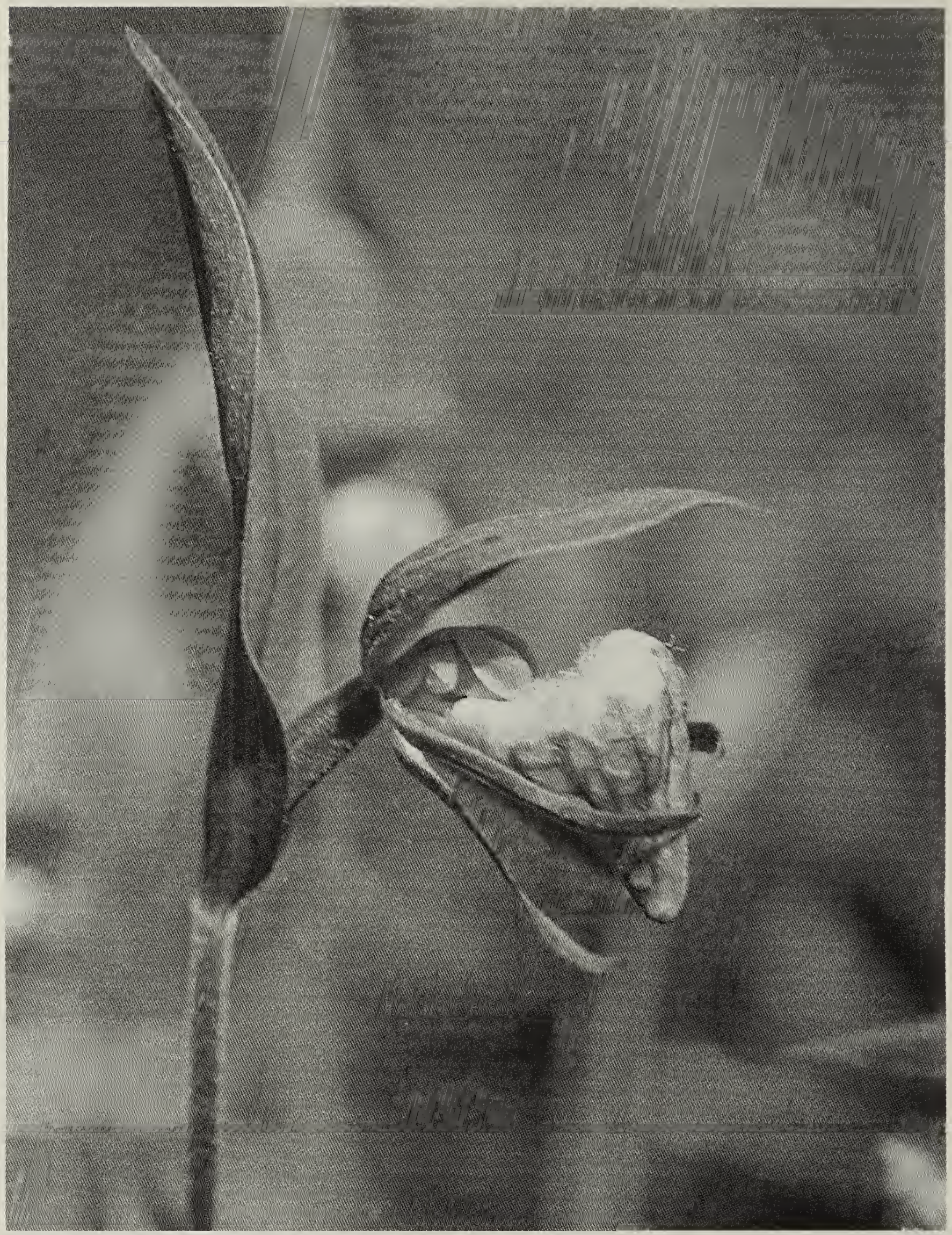

emotion, from childhood days in the woods near Porcupine Plain, Saskatchewan. There are two varieties on the prairies: the Large Yellow Lady's-slipper and the Small Yellow Lady's-slipper. ${ }^{3}$ This species grows mostly in the boreal forest, but is sometimes found along roadways and railroad tracks, as well as in aspen groves and wetland edges, in more southern ecoregions. Like many orchid species, however, it is relatively rare. To find it is a privilege which should not be abused. Take inspiration from it, perhaps a photograph or two - carefully - and let it be.

The Stemless Lady's-slipper (Cypripedium acule) also called Pink 


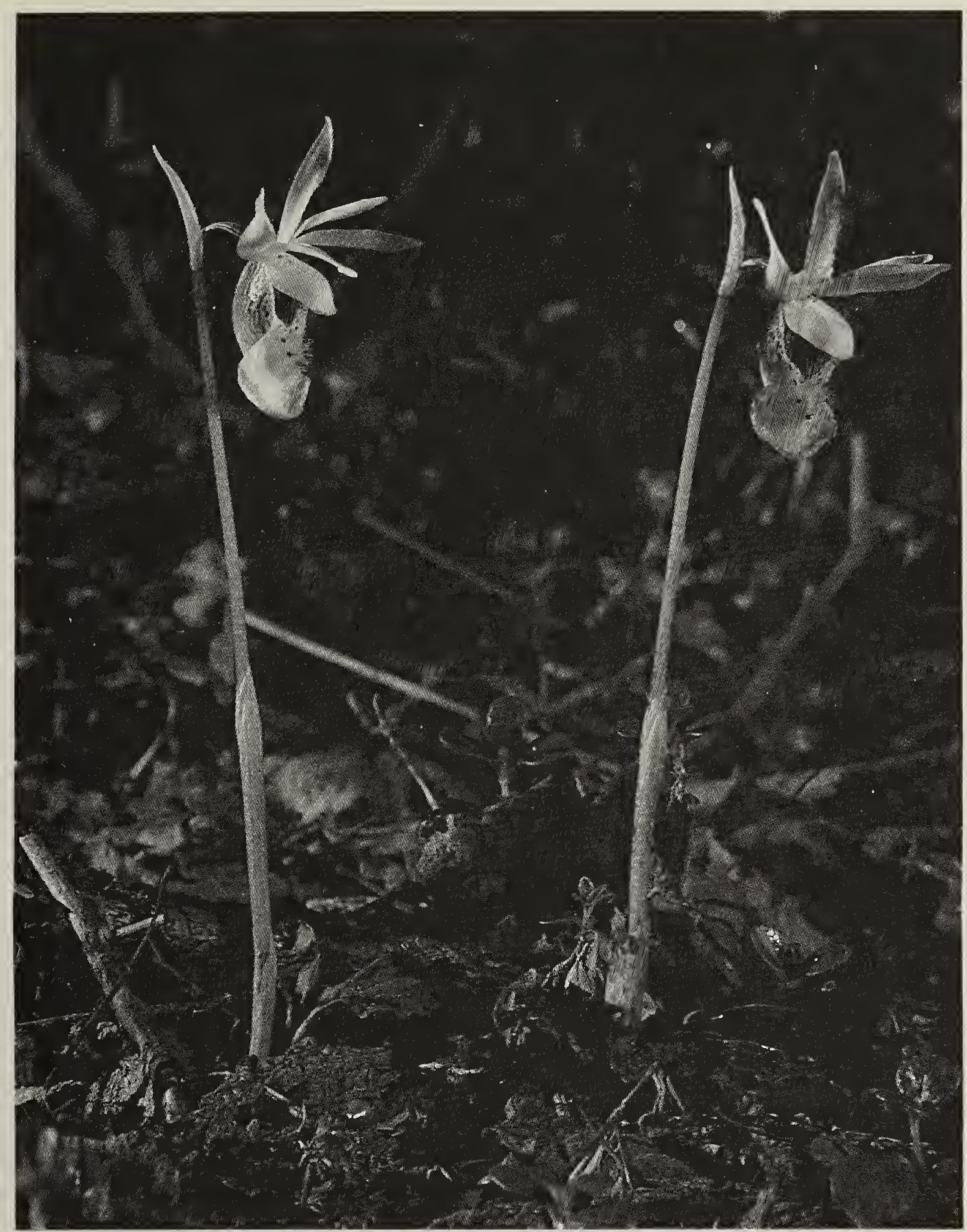

Lady's-slipper or Moccasin Flower, is another species whose range is broad, extending from the Atlantic Provinces, through the boreal forest to Northern Manitoba, Saskatchewan and the Northwest Territories. Prince Edward Island claims it as its floral emblem, but it is cherished by many other Canadian naturalists. I can still feel the excitement that flooded over me when I first discovered it in a provincial park north of Lake Superior where we camped overnight in the early 1970s; and I prize the pictures I took of them at that time, one of which reminds me, for some reason, of a scolded dog with its tail between its legs. It prefers moist woods and wetland areas of the boreal forest, but like the Yellow Lady'sslipper, is rare.

The most showy of our lady's- 


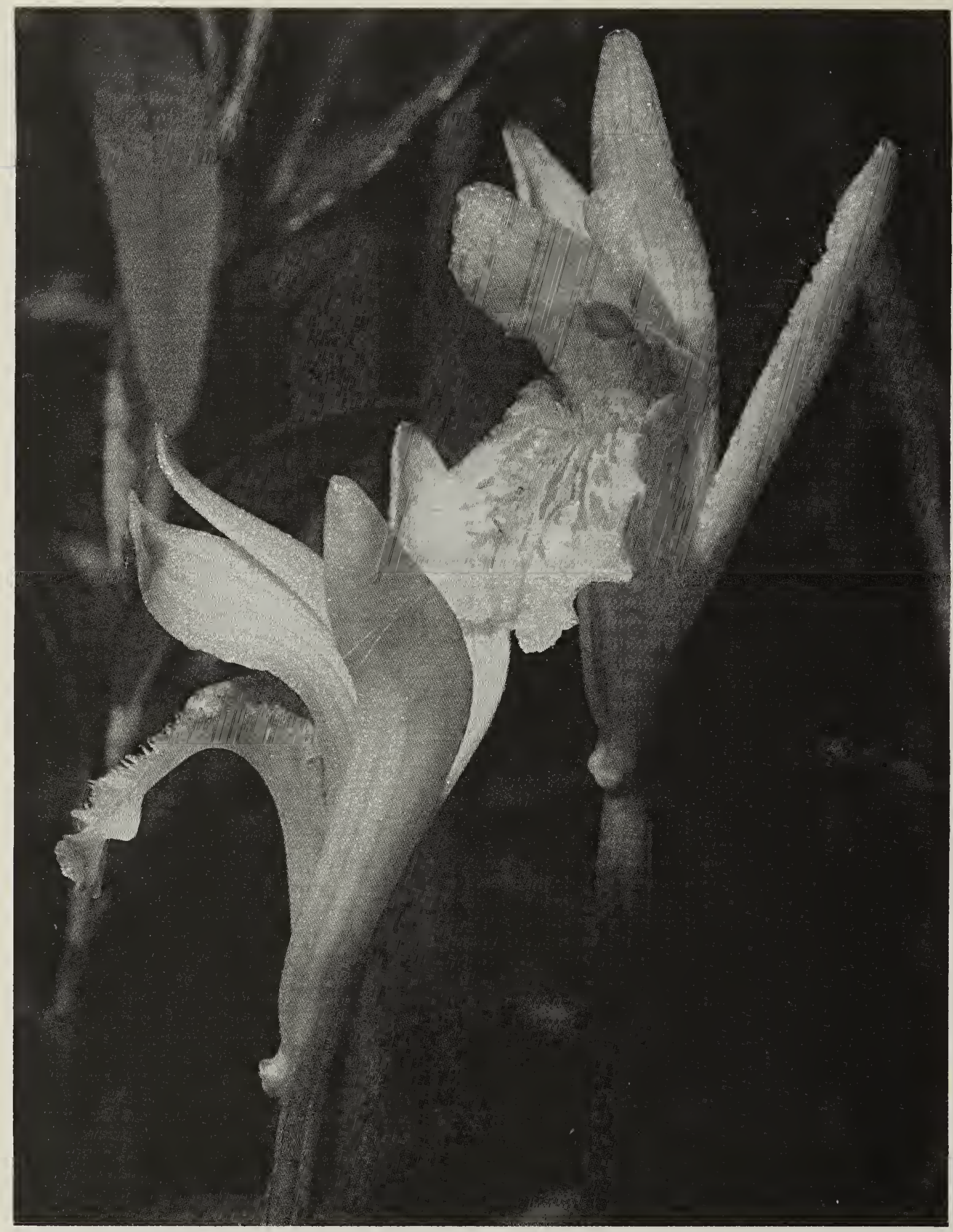

slippers is, not surprisingly, called the Showy Lady's-slipper (Cypripedium reginae). It is truly elegant. Pure white sepals and petals act as a foil for the magnificent rose-purple pouch. A clump I photographed on the Bruce Peninsula in Ontario was almost a meter in height and the blossoms were at least four centimetres in length and breadth. This is another species that likes wetland areas; it is rare, if not absent, in Saskatchewan but has been more commonly found in the southern part of Manitoba and as far north as Mafeking. ${ }^{4}$

The lady's-slipper which has been the most adventurous in northern climes is Franklin's Lady's-slipper (Cypripedium passerinum), also called the Sparrow's Egg Lady's- 


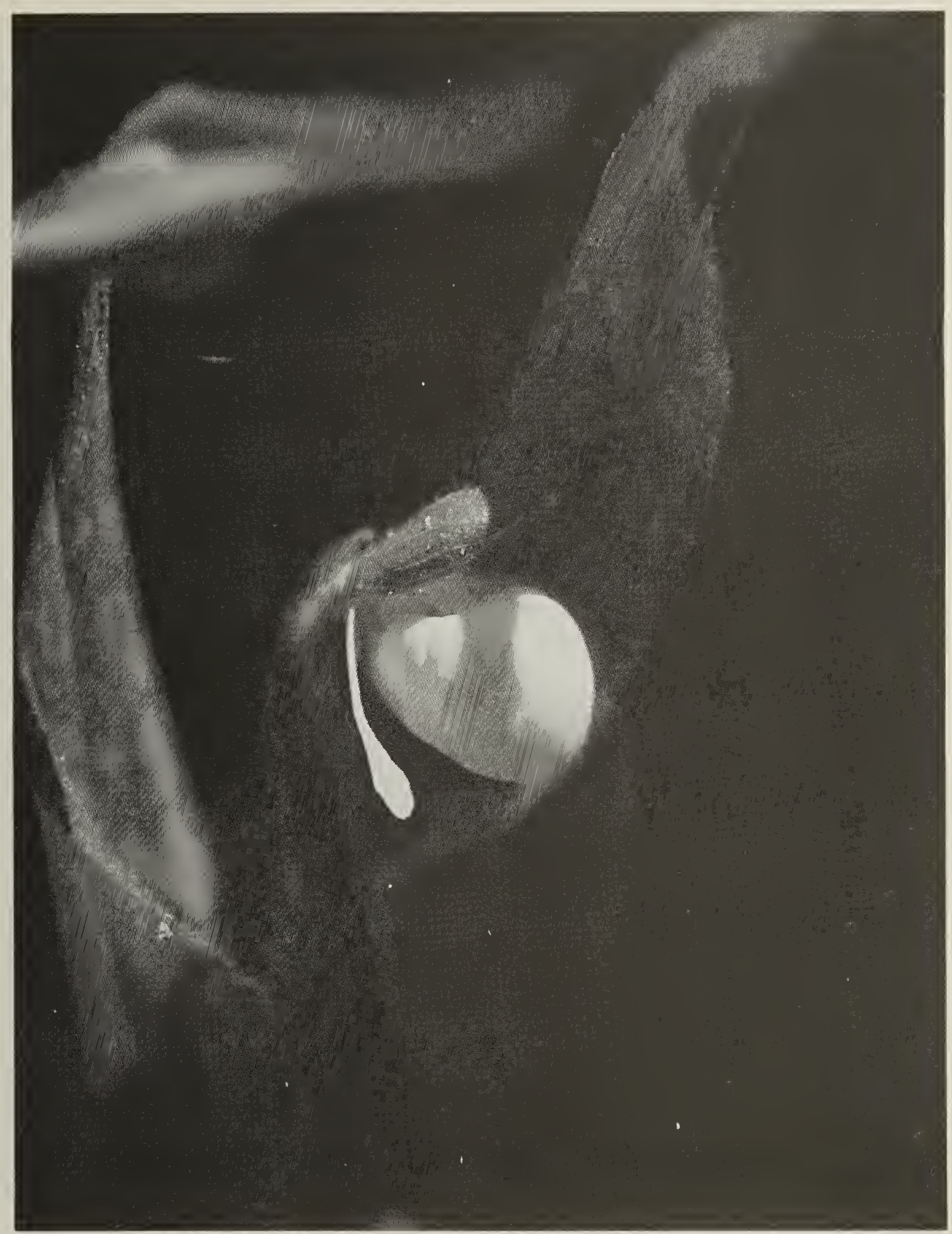

Franklin's Lady's-slipper

Roy John

slipper. Its range extends over most of Alaska and the Yukon territory, but has dipped down as far as the southern mountain region of Alberta. In Saskatchewan and Manitoba it is found mostly in the boreal forest, although the Cypress Hills claim locally abundant populations. In general - like the Yellow, Pink and Showy Lady's-slippers - it is rare.

Three other Cypripedium species are even more rare in the prairie provinces: the small red and white Ram's-head Lady's slipper (Cypripedium arietinum); the alpine Mountain Lady's-slipper (Cypripedium monatanum), the white lip of which is enhanced by a backdrop of striking brownish-purple petals and sepals ${ }^{5}$; and the sun-loving Small White Lady's-slipper (Cypripedium candidum), which is now officially listed 


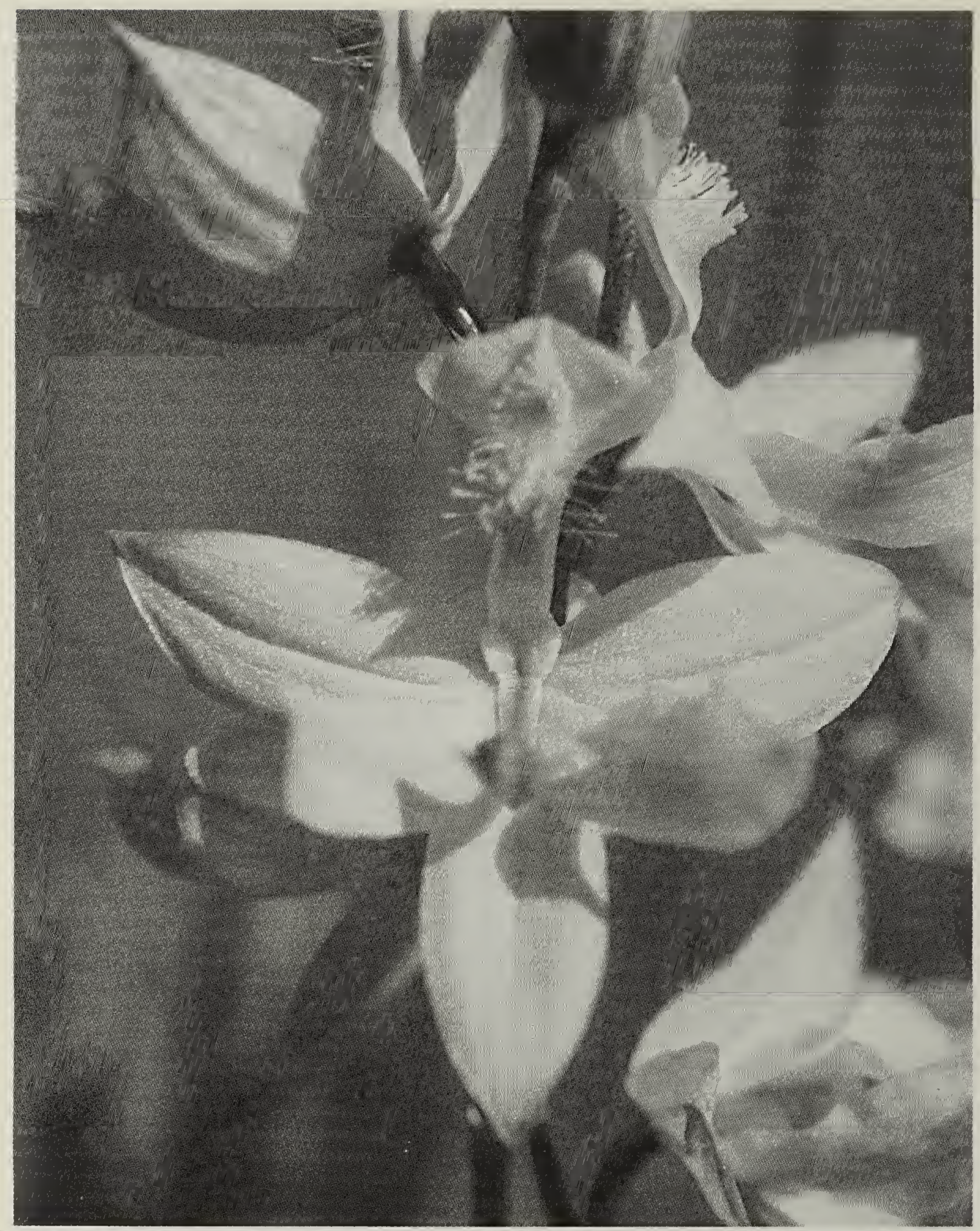

in Canada as an endangered species.

The scientific generic name for the lady's slippers, Cypripedium, is derived from two greek words meaning Aphrodite's little shoe, hence the name lady's slipper. Aphrodite, or Venus, was the Greek goddess of love and beauty who the famous ancient Greek author, Homer, called Cyprian.
In the ways of love, lady's slippers use their beauty to attract appropriate suitors, but make them work before they give them what they seek. The suitor, which is usually a species of bee, alights on the alluringly coloured and slippery lip and falls headlong into the depths of the slipper. Not liking to be trapped, the bee tries to escape the way it got in, but the inside walls of the pouch are as slippery as the place where it 


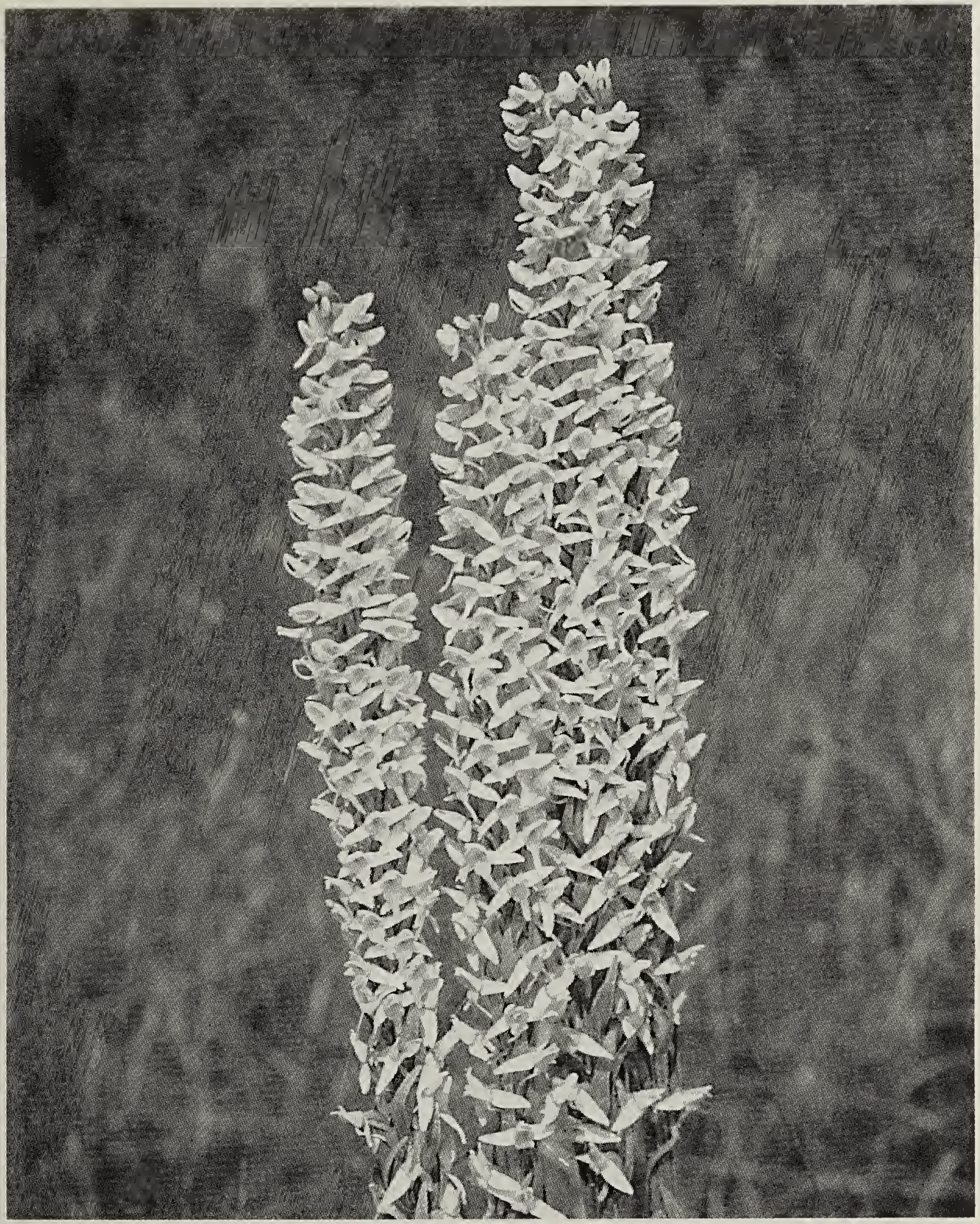

originally landed. An alternative escape route must be found. This the orchid obligingly provides in the form of a back door. To get through this back door, however, the insect must squeeze past the anther with its pollen sack which sticks to the visitor's back. After putting the bee through so much, the flower pays generously for services rendered. A feast of food hairs, each with a tasty serving of protein and sugar, is provided. ${ }^{6}$
Homer, in the Odyssey, relates how Odysseus, the hero of the epic poem, was detained for seven years on an island by a sea nymph called Kalypso. It was after this nymph that another exquisite orchid was named: Calypso bulbosa, the Fairy Slipper, familiar to those who visit the mountains, boreal forest, or Cypress Hills in early June. It is not large and showy, but is nevertheless among the world's most beautiful orchids. 


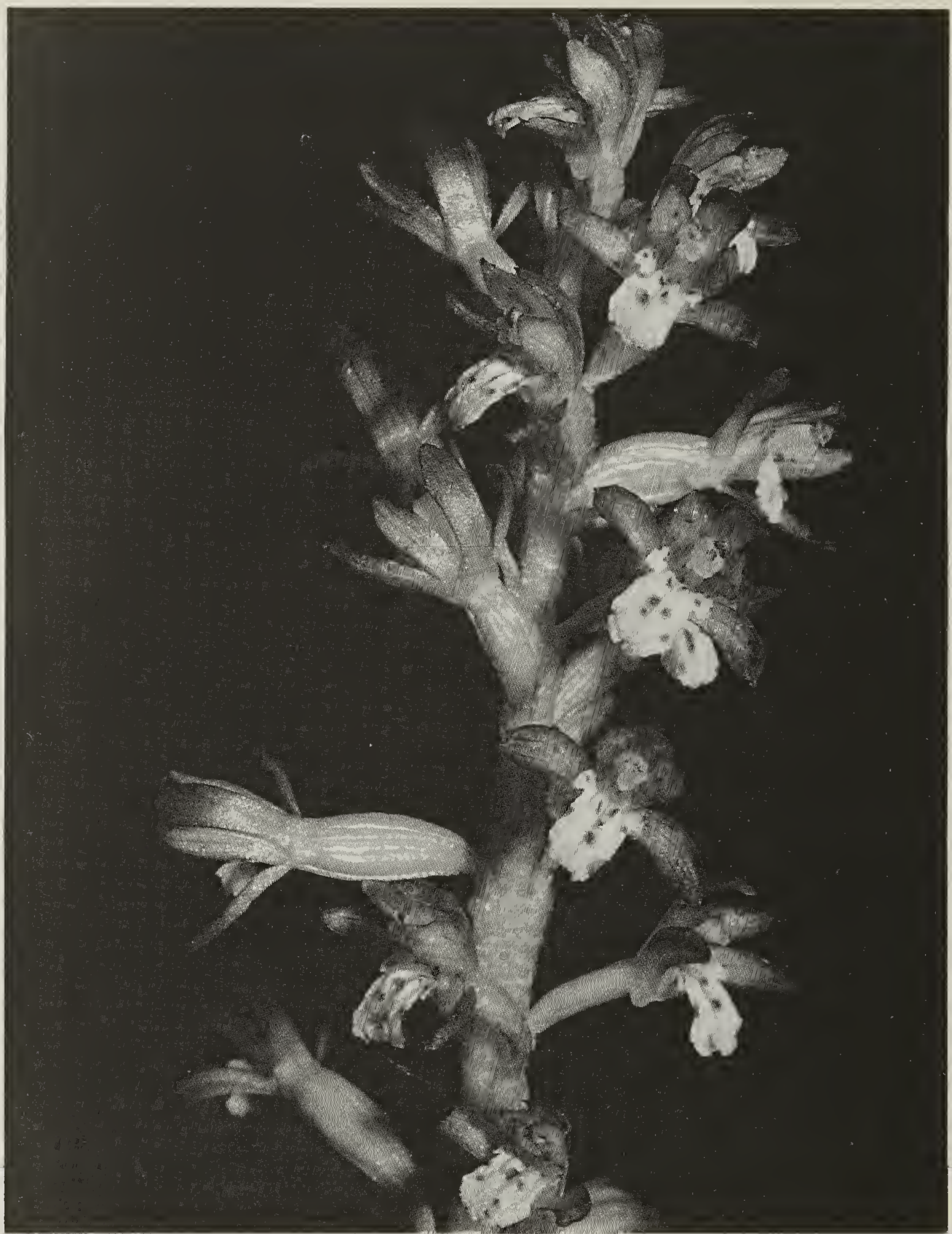

John Muir, the renowned naturalist and conservationist, when he first saw it in a southern-Ontario swamp, after a very strenuous day of searching for it, called the experience one of two "supreme moments of my life." He wrote:

"I found beautiful Calypso on the mossy bank of a stream ... It seemed the most spiritual of all flower people I had ever met. I sat down beside it and fairly cried for joy ... How long I sat beside Calypso I don't know. Hunger and weariness vanished, and only after the sun was low in the west I splashed on through the swamp, strong and exhilarated as if never more to feel any mortal care." 


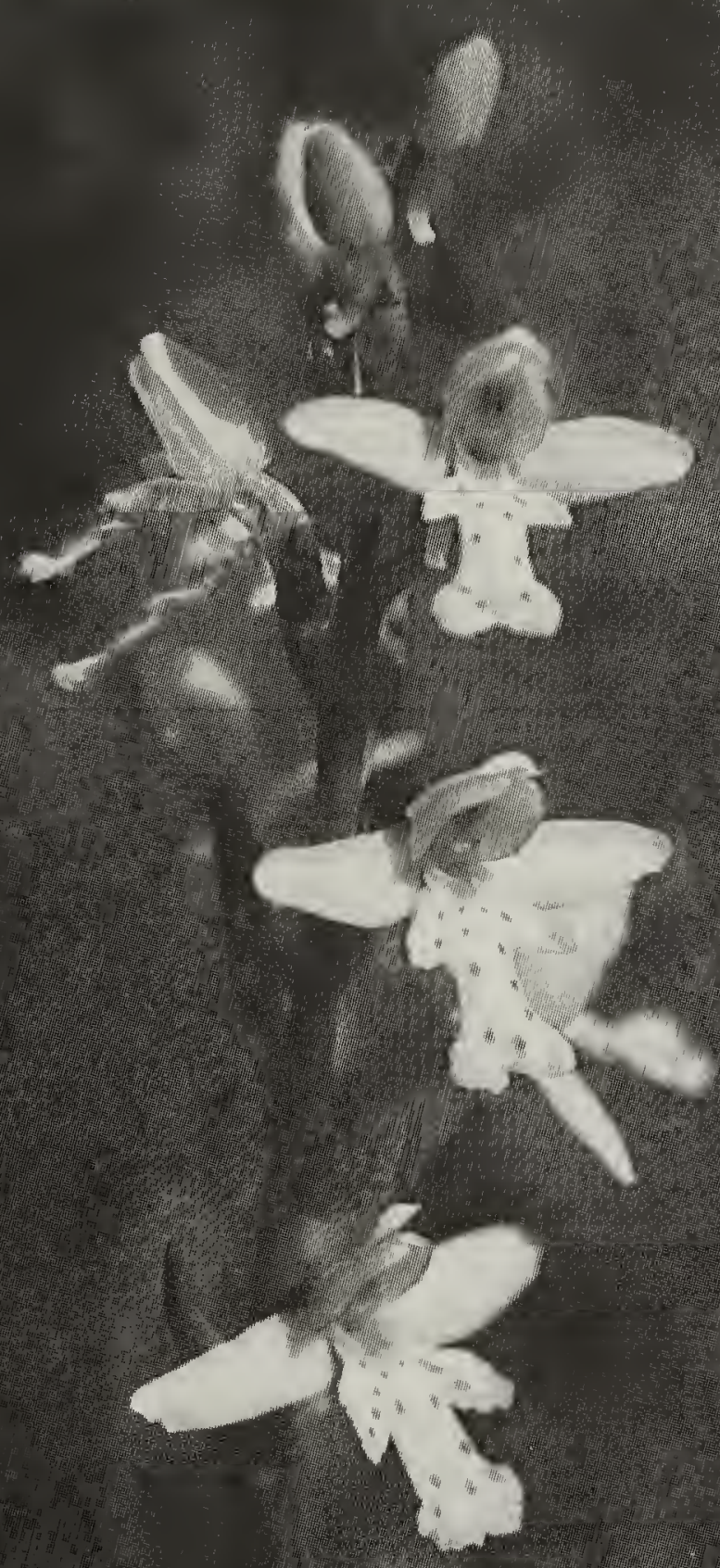

It was on Flower Pot Island off the tip of Ontario's Bruce Peninsula where I first saw Calypso bulbosa, an experience perhaps not as intense as the one John Muir described but one that nevertheless left a deep impression on my memory. Calypso truly does have irresistible powers to detain.

Surprisingly, however, when this gorgeous sweet perfumed creature detains its pollinator - not only a bee, but, appropriately, a queen bee - it gives absolutely nothing to its royal visitor. ${ }^{8}$ The queen, mind you, is smart enough to be fooled no more than once; which means that the Fairy Slipper does not have a high rate of fertilization, only about $25 \%$. It compensates for this by producing an enormous number of 


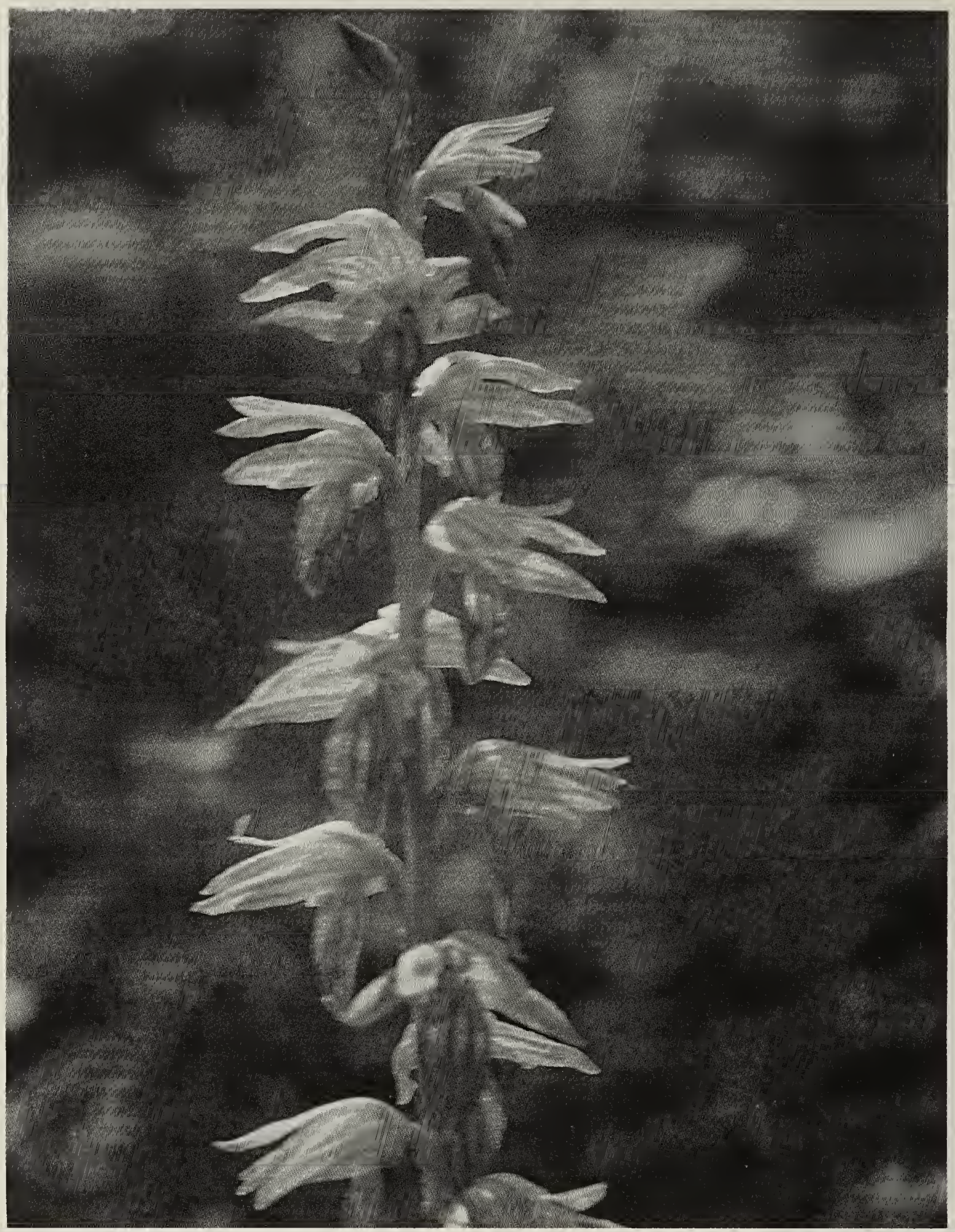

seeds - as much as 25,000 per flower. (I wonder who did the counting?)

Named after another nymph of Greek mythology is Arethusa bulbosa, Dragon's Mouth Orchid, or Swamp Pink, which I have never seen, but which is at the very top of my orchid wish-list. Far from being as fearsome as its name suggests, the Dragon's Mouth is quite small and has been described as one of the most beautiful orchids in Canada: a rosy pink, with an elaborate wavy-edged lip adorned with decorative purple blotches and many fine white hairs. It grows only in wet meadows and bogs, which is probably why it was named after the mythic nymph, Arethusa, who was transformed into a bubbling spring to 


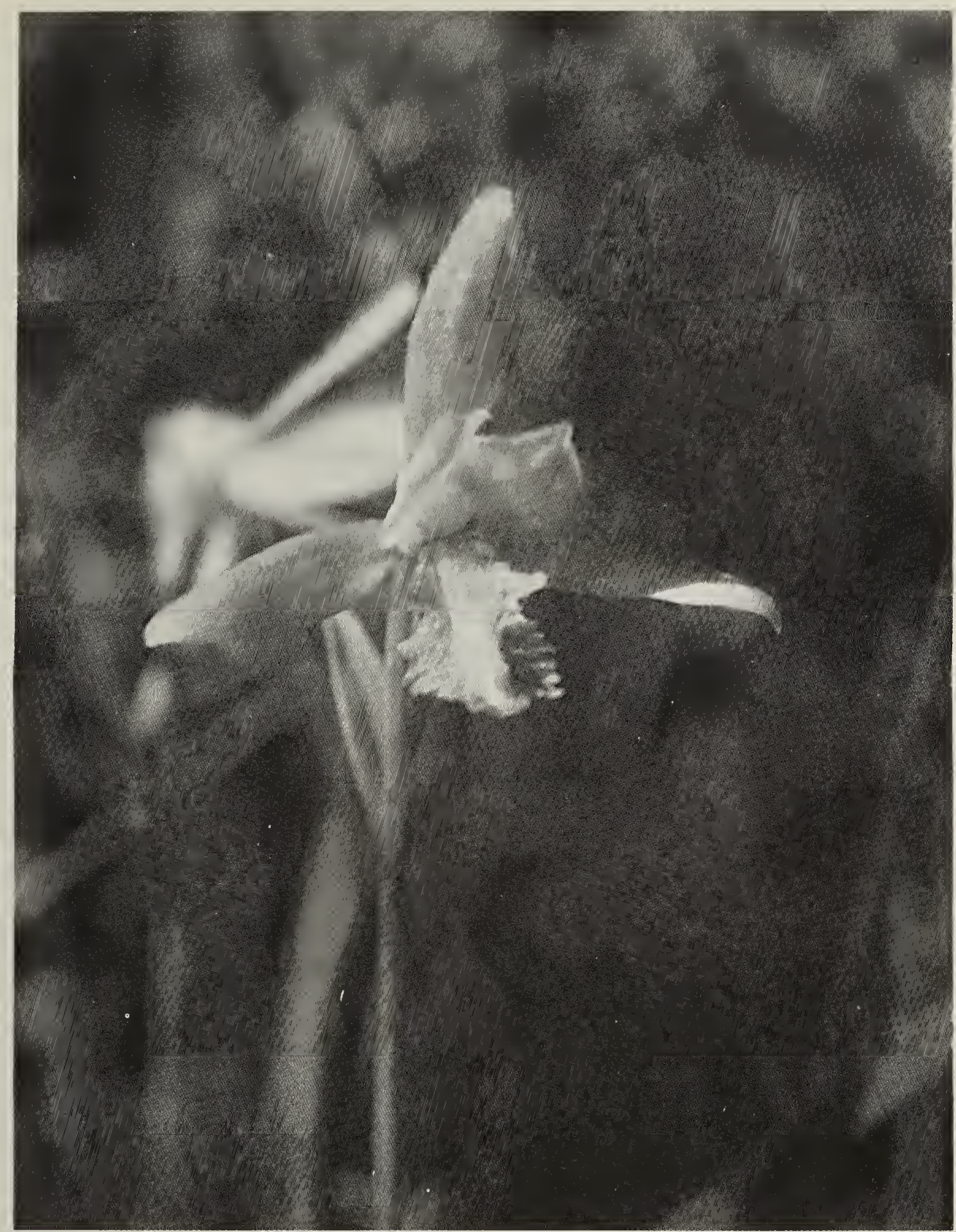

escape an ardent river god's pursuit. Dragon's Mouth has been found in the Hudson Bay area of Saskatchewan and in a few places in Manitoba, but it is very rare. Mostly an eastern species, its range extends throughout the Atlantic provinces, Quebec and Ontario and reaches its western limit in our area.

Not to be confused with it is the
Grass Pink (Calopogon pulchellus), another predominantly eastern wetland species similar in colour but very different in appearance. It ventures into the prairie provinces only as far as southeastern Manitoba. One of my personal favourites, it has taken my breath away on both occasions that I have seen it. One might call it the upside-down orchid, as the elaborate lip which is usually at the 


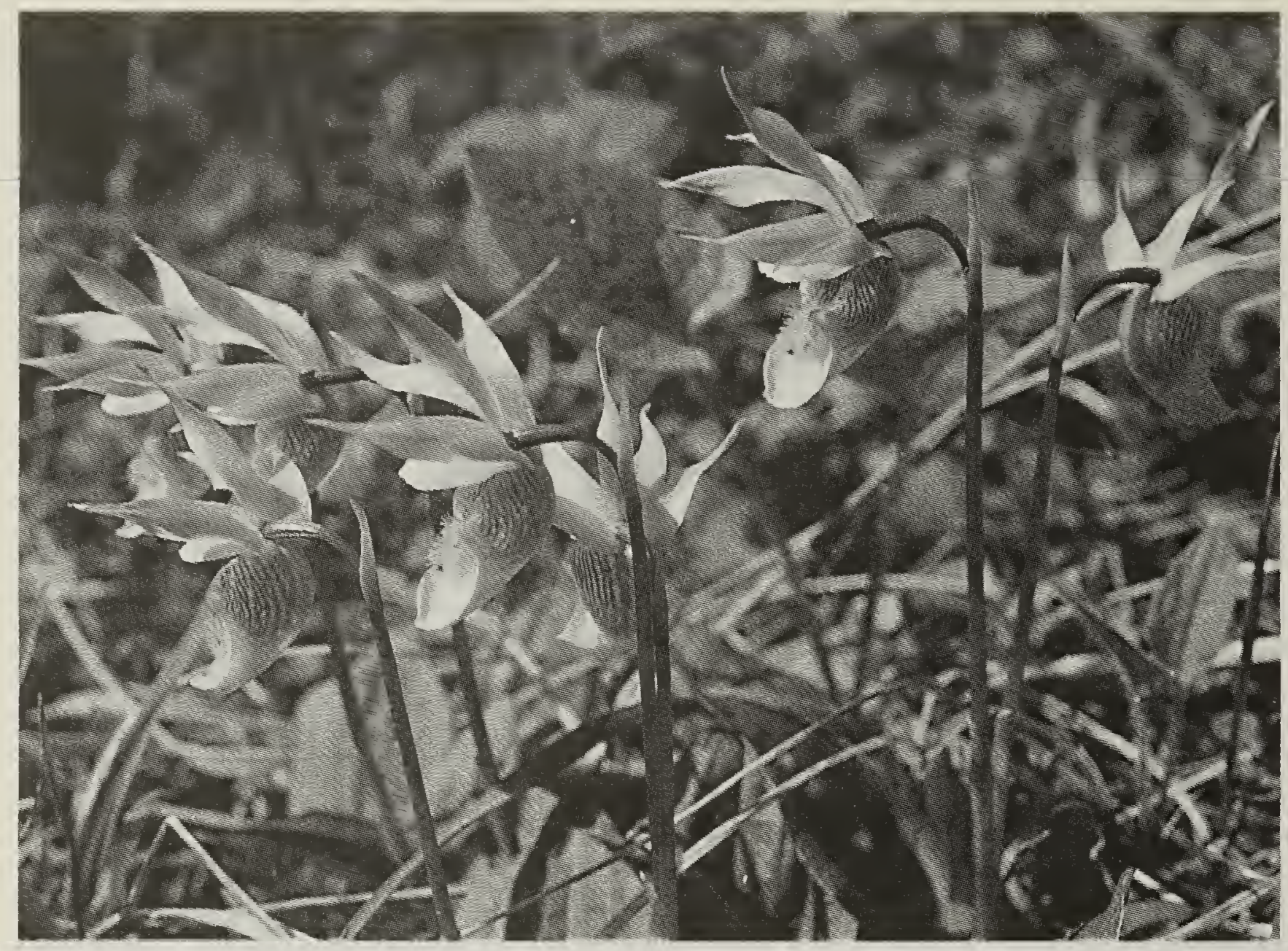

A. Clare Hume

bottom is, in this case, at the top. There is a fascinating reason for this reversal of form. The upright lip is decorated with a brightly colored cluster of false stamens which attract the appropriate insect. When the insect lands on this deceptive beard, the lip, which has a kind of hinge, suddenly falls forward tossing the insect on its back against the reproductive column where it collects a glob or two of pollen and, at the same time, deposits whatever cargo it is carrying (The pollen of orchids is not in the form of fine dust, but of a sticky coagulated mass of pollen grains called a pollinium). Budd states that both Calopogon and Arethusa orchids are very rare. ${ }^{1}$

Less rare, thankfully, is the lovely little Round-leaf Orchid (Orchis rotundifolia ${ }^{9}$ ) which may be found in wet or moist woods and bogs throughout the boreal forest and in the Cypress Hills. The cluster of tiny flowers reminds one of a chorus of angels. Look closely and you will see that each one has a flowing white robe bedecked with red spots, has pure white wings, and wears an elegant poke bonnet trimmed with pink. My imagination even sees little mouths opening wide in song.

Bonnets are also worn, though less obviously, by the individual blossoms of the Hooded Lady's-tresses (Spiranthes romanzoffiana). The torch-shaped, snow-white flower clusters of this species stand out strikingly in the moist woods and wetlands where it feels at home. One of the more widespread orchids in North America, it grows across the continent, from Alaska to Newfoundland, and in the west as far south as Arizona and California.

The Slender Lady's-tresses, however, is my favourite of the two species. Spiranthes gracilis is more delicate in appearance. Minute white flowers spiral gracefully around a very slender, but tall, flower stalk, and a basal rosette of oval leaves acts as a foil for their beauty. Mostly an eastern species, the Slender 
Lady's-tresses in the prairie provinces are confined to southeastern Manitoba and are rare.

One of the most fragrant of our orchid species is the White Bog Orchid (Habenaria dilatata). It is tall, up to $125 \mathrm{~cm}$ in height, with a graceful tapering spike of waxy white blossoms. Quite fitting is a name sometimes given it: "Bog Candle." It stands out conspicuously at some distance, and like some candles, the scent is delectably spicy.

Following the Nature Saskatchewan Spring Meet in the Cypress Hills this year, I found a spectacular clump of Spotted Coralroot (Corallorhiza maculata), and spent a good half hour or so getting pictures. I had never seen such a large clump. It contained twenty flower stalks.

There are three coralroot species that grow in our region, none of them capable of photosynthesis. They are the saprophytic species which get their nutrients, in a symbiotic relationship with fungi, from organic material in the soil. The Spotted Coralroot and the Striped Coralroot (Corallorhiza striata) which I also saw in the Cypress Hills while at the Spring Meet, are reddish in overall appearance and have many flowers creeping up the stem. As their common names imply, one has red spots on a white lip while the other has red stripes. The Early Coralroot (Corallorhiza trifida) has fewer and less tightly clustered flowers with a mostly all-white lip and lacks the general reddish appearance of the other two coralroots.

There are other species of orchid that grow in our three prairie provinces - the twayblades, the adder'smouths, the rattlesnake-plantains, to mention a few. I hope you will check them out in the flower books, and someday have the opportunity to see them. They are not as showy as the species I have mentioned, but each has its own fascination.

One thing to be aware of in looking at field guides and other books on orchids is that there is some confusion about the names. Taxonomists do not always agree on scientific names; ${ }^{9,10,11}$ and there are often several common names used for a species. An example of both types of taxonomic confusion is Habenaria obtusata which some scientists call Platanthera obtusata, and which has at least four common names: Bluntleaf Orchid, Small Northern Bog Orchid, One-leaf Rein Orchid and Blunt-leaved Fringed-Orchid.

It is not only the coralroots that depend on fungi for growth. All orchids require a relationship with fungi in order to germinate and begin their growth. Orchid seeds are extremely small and light. This enables them to travel well. They are ideally equipped to ride the air currents and may be carried thousands of kilometres. Not only that, they are able to remain in the dry and frigid upper atmosphere for as many as ten years and still maintain their fertility. ${ }^{12}$ Orchid seeds are tough, prolific and are superb travellers, yet once they get settled in an appropriate habitat they are completely helpless on their own. They lack sufficient nutrients to nourish the embryo. Each seed has to wait until a certain species of fungus finds it. When the meeting between orchid seed and fungus mycelium takes place a strange love-hate relationship begins. Both orchid seed and fungus need each other, yet at the same time try to destroy each other. The fungus takes the offensive. Its mycelium attacks the orchid seed and starts feeding on the seed's very meager store of nutrients. The victim, however, soon becomes the aggressor. The seed turns into a parasite, digesting and living off of the fungus. If all goes well a balance of power is 


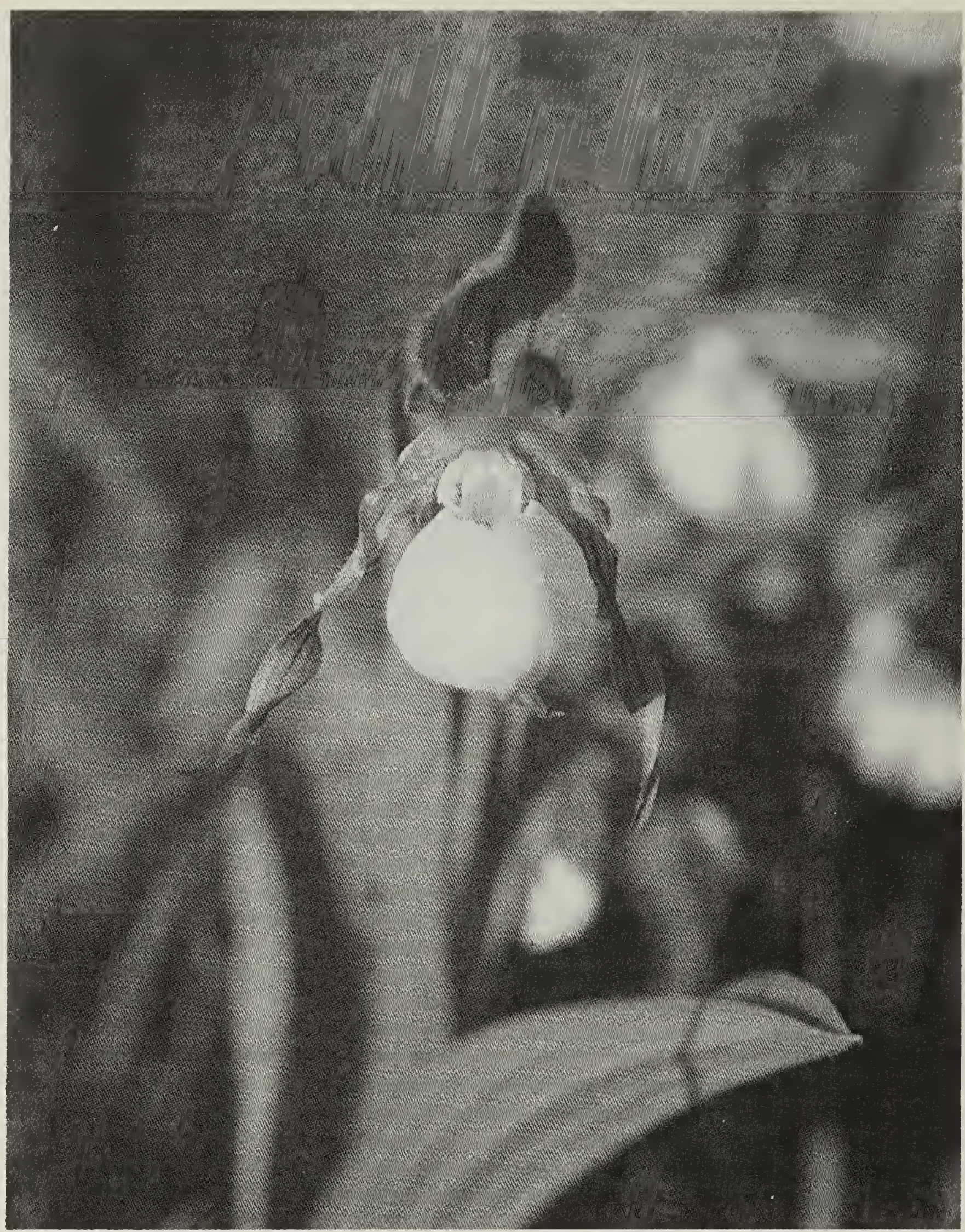

Roy John

reached and the two learn to live together, mutually benefiting from the relationship, through the period of the orchid's germination and early growth. A balance of power is not always the result, however. If the fungus is too vigorous it will devour the orchid embryo, and if the orchid is more robust, it will kill the fungus and thus destroy its own life-support system - unless another appropriate fungus finds it. Studies show that only a small number of fungi will enter into a symbiotic relationship with a particular species of orchid; and only those species closely related to the orchid will do the same with that particular group of fungi. ${ }^{13}$

When human impacts on soil such as fertilization and the spread of toxic chemicals destroy fungi, orchid species that depend on them also disappear. This is one reason why 
many orchids are rare. Other reasons for the dwindling of orchid populations are the destruction of their habitat - the decimation of forests and drainage of wetlands in particular - and the human compulsion to pick and to transplant.

Cultivated hybrid species thrive in commercial greenhouses, conservatories, and under lights in private homes. Their sheltered worlds are secure. Many wild orchid species, on the other hand, are in danger of extinction. A number of eastern Canadian species are listed by The Committee on the Status of Endangered Wildlife in Canada (COSEWIC), as either endangered, threatened or vulnerable. The situation in the prairie provinces is somewhat better. The only orchid native to our area listed by COSEWIC is the Small White Lady's Slipper, which is "endangered." Nevertheless, not many of our prairie orchid species are prolific. The uncommonness of most of them should alert us to the fact that we cannot simply take them for granted. What a terrible loss it would be if any one of them should disappear because of human greed or carelessness.

Orchids are among Earth's most precious jewels. Get to know them. Like John Muir, when he first saw the Fairy Slipper, celebrate their presence. Discover that they are not just exotic flowers of far-away jungles and south-sea islands; they are treasures of our own prairie province ecosystems, here to delight the hearts of ariy sensitive person who loves nature and, hopefully, to delight our grandchildren and their offspring for many generations to come.

1. BUDD, A.C. 1979. Budd's Flora of the Canadian Prairie Provinces, Research Branch Agriculture Canada, Ottawa. 270-279.
2. VANCE, F.R., J.R. JOWSEY and J.S. MCLEAN. 1984. (Revised and Expanded) Wildflowers Across The Prairies, Western Producer Prairie Books, Saskatoon. 36-50.

3. For a helpful. description of the characteristics and the range of these two varieties see VERN HARMS. 1986. The Yellow Lady's Slipper Varieties in Saskatchewan and Western Canada. Blue Jay 44:87-95.

4. ERSKINE, A.J. 1997. A Birder Looks At Flowers. Blue Jay 55:108.

5. HARMS, in the March 1985 Blue Jay, reported that this species had been seen in Saskatchewan's Cypress Hills west of Loch Leven.

6. For a more detailed description of the pollination of lady's-slippers see HILDA SIMON. 1975. The Private Lives of Orchids, Lippincott. p. 67.

7. Quoted in Ontario Naturalist, Vol. 16, No.2, April 1976, p. 5.

8. See Nature Canada, Spring 1994, $9 f$, for a full description of Calypso pollination by queen bees in Alberta's Kananaskis area.

9. Taxonomists differ as to the scientific name of this species. Budd's Flora and Wildflowers Across the Prairies both use Orchis rotundifolia as does JOHNSON, KERSHAW, MacKINNON and POJAR. 1995. Plants of The Boreal Forest and Aspen Parkland. Lone Pine, Edmonton. p. 92. W. PETRIE, however, in Guide to Orchids of North America, Hancock House, Vancouver and Washington, 13, uses the name Amerorchis rotundifolia.

10. PETRIE uses the scientific name Spiranthes laciniata for this species.

11. VANCE, JOWSEY and MCLEAN along with BUDD use the name $\mathrm{Ha}$ benaria dilatata. PETRIE, on the other hand, along with JOHNSON, KERSHAW, MacKINNIN and POJAR, uses Platanthera dilatata for this species.

12. ANDERSON, F.J. 1981. Orchids, Abbeville Publishers, New York. p. 8.

13. DRESSLER, R. 1983. The Orchids, Natural History and Classification, Harvard University Press, Cambridge, Mass. and London, England. p. $78 f$. 